\title{
Pengaruh Kuat Arus dan Waktu Elektroplating Nikel terhadap Kekerasan dan Laju Korosi Baja
}

\author{
Kardiman*, Najmudin Fauji \\ Program Studi Teknik Mesin, Universitas Singaperbangsa Karawang \\ Jl. HS.Ronggo Waluyo, Puseurjaya, Kabupaten Karawang, Jawa Barat, Indonesia 41361 \\ *E-mail: kardiman@ft.unsika.ac.id
}

Diterima: 14-07-2021; Direvisi: 26-07-2021; Dipublikasi: 27-08-2021

\begin{abstract}
Abstrak
Elektroplating merupakan proses pengendapan ion-ion pada suatu logam dasar katoda pengendapan katoda terjadi karena perpindahan ion-ion bermuatan listrik dari anoda dengan perantara larutan elektrolit, terjadi terus menerus pada tegangan konstan sehingga terjadi pengendapan dan menempel pada logam. Mesin yang digunakan pada penelitian ini merupakan mesin yang telah dibuat sebelumnya, kapasitas tangki 50 liter larutan elektrolit dan tegangan yang dihasilkan sebesar 24 volt dan arus sebesar 50 ampere. Tujuan dari penelitian ini yaitu mengetahui pengaruh besar arus listrik 2,3 ampere, serta lama waktu pencelupan 10,20, dan 25 menit terhadap nilai kekerasan dan laju korosi. Dari hasil penelitian, foto makro terlihat bahwa pada proses pencelupan 10 menit nikel yang menempel masih kurang rata dan terlihat masih belum sempurna serta sedikit kasar, waktu peceleupan 20 menit terlihat bahwa nikel yang menempel sudah merata dan permukaan spesimen lebih halus. Hasil pengujian kekerasan terendah terjadi pada kuat arus elektroplating 2 ampere dengan lama pencelupan 25 menit sebesar 16.33 HRc dan nilai kekerasan tertinggi dihasilkan pada kuat arus 3 ampere dengan pada pencelupan 25 menit. Hasil pengujian laju korosi paling tinggi terjadi pada raw material yaitu 2424.25 mmpy sedangakan nilai laju korosi terendah adalah 1385.28 mmpy dengan lama pencelupan 25 menit dan kuar arus 3 ampere.
\end{abstract}

Kata kunci: elektroplating; kuat arus; laju korosi

\begin{abstract}
Electroplating is the process of depositing ions in a basic metal cathode. The deposition of the cathode occurs because the electrically charged ions from the anode mediated by the electrolyte solution, occur continuously at a constant voltage so that precipitation occurs and sticks to the metal. The machine used in this study is a machine that has been made before, the tank capacity is 50 liters of electrolyte solution and the resulting voltage is 24 volts and a current of 50 amperes. The purpose of this study is to determine the effect of electric current 2.3 amperes, and immersion time 10,20, and 25 minutes on the value of hardness and corrosion rate. The results of the study, macro photos show that in the 10-minute immersion process the nickel adhered was still uneven and looked still imperfect and a little rough, the 20 minutes of immersion time showed that the nickel adhered was evenly distributed and the specimen surface was smoother. The lowest hardness test results occurred at 2 amperes electroplating current with 25 minutes immersion time of 16.33 HRc and the highest hardness value produced at 3 amperes current at 25 minutes immersion. The highest corrosion rate test results occurred in raw material, namely 2424.25 mmpy, while the lowest corrosion rate value was 1385.28 mmpy with a immersion time of 25 minutes and a current of 3 amperes.
\end{abstract}

Keywords: electroplating;electrical voltage;corrosion rate

\section{Pendahuluan}

Elektroplating merupakan salah satu metode pelapisan logam yang sering disebut elektrodeposisi, atau proses pengendapan logam pelapis pada logam induk dengan cara elektrolisa [1]. Logam yang digunakan sebagai pelapis adalah nikel, chromium, mangan, arsen, platinum, aurum, plumpun, dan logam-logam lainnya Salah satu logam yang dapat digunakan sebagai pelapis pada plat baja, tembaga atau logam lain agar terlindungi dari korosi dan menghasilkan permukaan yang halus serta mempunyai bentuk yang mengkilap adalah nikel. Nikel tahan terhadap panas, tahan korosi, tidak rusak oleh air laut dan alkali, namun nikel bisa rusak oleh asam nitrat dan sedikit terkorosi oleh asam khlor dan asam sulfat [2]. 
Kardiman dkk /Jurnal Rekayasa Mesin

p-ISSN: 1411-6863, e-ISSN: 2540-7678

Vol.16, No.2, Agustus 2021, hal. 172-180

Dalam teknologi pengerjaan logam, proses elektroplating atau lapis listrik termasuk kedalam proses pengerjaan akhir (metal finishing). Fungsi utama dari pelapisan logam adalah melindungi logam dasar dari korosi baik itu melindungi dengan logam yang lebih mulia seperti pelapisan platina, emas dan baja atau melindungi dengan logam dasar yang kurang mulia seperti pelapisan seng pada baja. Elektroplating juga memperbaiki kehalusan atau bentuk permukaan dan toleransi logam dasar, misalnya: pelapisan nikel, dan chromium [3, 4].

Seperti pada penelitian Basmal, dkk (2012) tentang pengaruh suhu dan waktu pelapisan tembaga-nikel pada baja karbon rendah secara elektroplating terhadap nilai ketebalan dan kekerasan. Dari hasil yang dapat diketahui bahwa ketebalan lapisan tembaga menyamai secara teori dan eksperimen terjadi pada suhu $40^{\circ} \mathrm{C}$ dengan waktu 10 menit yaitu $42.8 \mu \mathrm{m}$, sedangkan untuk lapisan nikel terjadi pada suhu $65^{\circ} \mathrm{C}$ dengan waktu 20 menit $65.4 \mu \mathrm{m}$. Dengan semakin tingginya suhu operasional nilai kekerasan permukaan dan ketebalan lapisan semakin meningkat [5].

Selain itu Arif, dkk (2015) telah melakukan penelitian tentang pengaruh variasi kuat arus listrik dan waktu proses elektroplating terhadap kekuatan tarik, kekerasan dan ketebalan lapisan pada baja karbon rendah dengan krom. Dari penelitian ini didapatkan ketebalan spesimen meningkat seiring bertambahnya arus dan waktu yang diberikan, Kekerasan yang dihasilkan berbanding lurus dengan kuat arus dan waktu dimana hasil kekerasan yg tertinggi dengan arus 27,3 ampere dan waktu 15 menit adalah 239,58 $\mathrm{kg} / \mathrm{mm}^{2}$ atau $12,621 \%$ lebih keras dibandingkan raw material. Untuk hasil uji tarik perbedaan kekuatan tarik raw material dengan nilai tertingi adalah 6,65\% dimana nilai tertinggi $627,8 \mathrm{~N} / \mathrm{m} 2[6]$

Syafrul (2015) telah melakukan penelitian tentang pengaruh pelapisan nikel pada laju korosi impeller pompa. Dari hasil penelitian laju korosi menunjukan bahwa impeller yang telah dilapisi Nikel (Ni) dengan waktu pelapisan 8 menit terendah yaitu sebesar 0.002 mpy, dan laju korosi terhadap impeller yang tidak dilapisi sebesar 0,182 mpy [7]. Berdasarkan uraian diatas maka penulis menganalisis pengaruh waktu pencelupan dengan variasi 10, 15 dan 20 menit serta pengaruh kuat arus 2 ampere dan 3 ampere pada proses elektroplating nikel terhadap kekerasan dan laju korosi baja.

\section{Material dan metodologi}

\subsection{Alat dan Bahan}

Alat yang digunakan dalam penelitian ini menggunakan mesin elektroplating yang telah dibuat sebelumnya, seperti yang ditunjukan pada Gambar 1. Alat Elektroplating
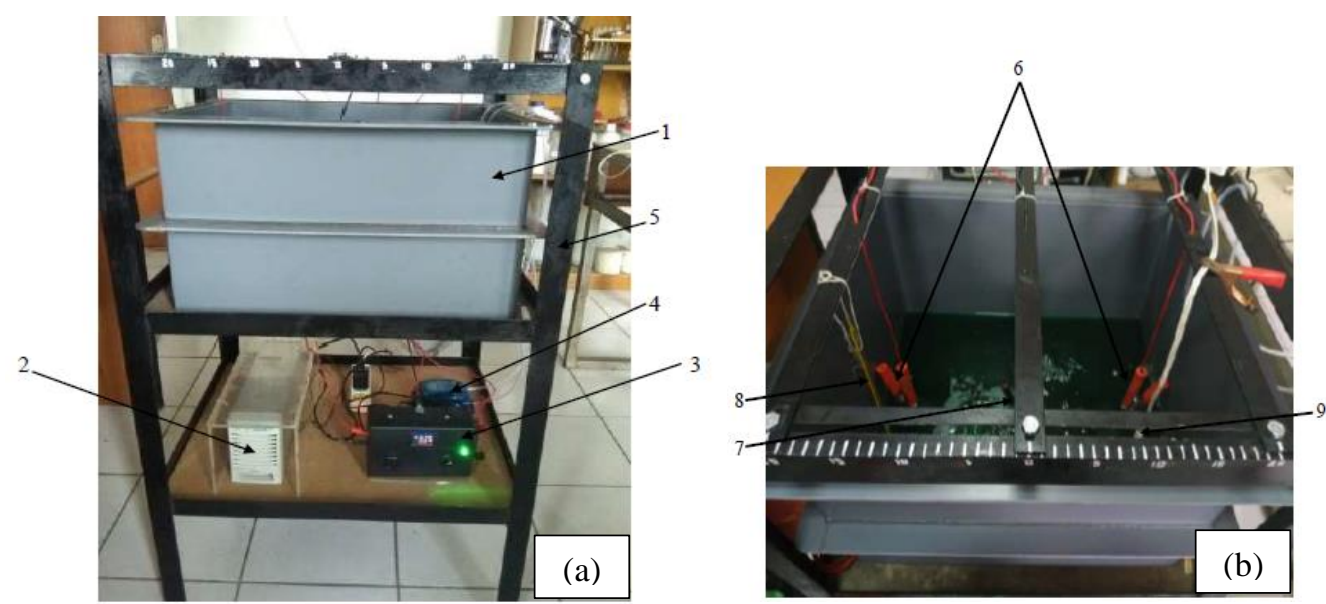

Gambar 1. Alat Elektroplating (a) tampak depan, (b) tampak atas 
Kardiman dkk /Jurnal Rekayasa Mesin

p-ISSN: 1411-6863, e-ISSN: 2540-7678

Vol.16, No.2, Agustus 2021, hal. 172-180

Gambar 1. merupakan alat elektroplating dengan kapasitas tangki 50 liter (1), rectifier yang digunakan pada alat ini memiliki tegangan output 24 volt dan kuat arus maksimum 50 ampere (2) yang dapat diatur melalui box controller (3). Selain itu, alat ini menggunakan airator yang berguna untuk mengalirkan oksigen dari udara (4), rangka pada alat ini merupakan besi siku 30x30 dengan ketebalan $1 \mathrm{~mm}$ (5), lalu terdapat dua buah penjepit anoda pada sisi bak penampungan (6) dan penjepit katoda pada bagian tengah. Selain itu terdapat termometer (8) dan heater yang berfungsi memanaskan larutan (9).

Adapun bahan dalam penelitian ini antara lain: spesimen pengujian yaitu baja SS400 Gambar 2.(a), nikel sulfat Gambar 4.(b), nikel chloride ( $\left.\mathrm{NiCl}_{6} \mathrm{H}_{2} \mathrm{O}\right)$ Gambar 4.(c), asam borat $\left(\mathrm{H}_{2} \mathrm{BO}_{3}\right)$ Gambar 2.(d), nikel brightener (Nisol 1206), nikel brightener (Nisol 1207), natrium hidroksida $(\mathrm{NaOH})$, asam sulfat $\left(\mathrm{H}_{2} \mathrm{SO}_{4}\right)$, asam klorida ( $\left.\mathrm{HCl}\right)$, anoda nikel, air laut serta beberapa alat bantu seperti mesin gerinda, alat uji kekerasan (Rockwell), kertas universal, neraca digital, timer, gelas ukur, termometer, amplas, pemanas air.

\subsection{Pembuatan Spesimen Uji dan Pembuatan Larutan Elektrolit}

Spesimen baja SS400, dibuat dengan Memotong spesimen uji berukuran 40x40 $\mathrm{mm}$ dan tebal $4 \mathrm{~mm}$ dilanjutkan dengan mengamplas hingga halus. Spesimen yang sudah bersih selanjutnya dicuci menggunakan larutan $\mathrm{NaOH} 10 \mathrm{~g} / \mathrm{lt}$ pada temperatur $60^{\circ} \mathrm{C}$. Proses selanjutnya spesimen direndam dalam larutan $\mathrm{HCl} 10 \%$ selama 5 menit dengan tujuan menghilangkan korosi. Setelah tahapan ini makan selanjutnya proses akhir yakni spesimen uji direndam dalam larutan $\mathrm{H}_{2} \mathrm{SO}_{4} 5 \%$ dan dilanjutkan pembilasan akhir menggunakan larutan aquades. Pembuatan larutan dimulai dengan memanaskan larutan aquades hingga mencapai suhu $40^{\circ} \mathrm{C}$ selanjutnya mencapurkan bubuk $260 \mathrm{gram} /$ liter Nikel Sulfat (NiSO4 7 $\mathrm{H}_{2} \mathrm{O}$ ), 35 gram/liter Nikel Chloride $(\mathrm{NiCl} 6 \mathrm{H} 2 \mathrm{O}), 35$ gram/liter Asam Borat $\left(\mathrm{H}_{2} \mathrm{BO}_{3}\right), 30 \mathrm{CC}$ dan $10 \mathrm{CC}$ Nikel Brightener (Nisol 1206, 1207) secara bersamaan dan diaduk hingga larut.

\subsection{Proses Elektroplating dan Pengujian Spesimen}

Proses elektroplating dimulai Menghubungkan Nikel (anoda) ke kutub positif dan baja SS400 (katoda) ke kutub negatif seperti terlihat pada Gambar 1 (b). Selanjutnya dilakukan proses variasi kuat arus 2,3 Amper dengan mengatur rectifier seperti terlihat pada Gambar Gambar $1(\mathrm{a}, 2)$ dan mengatur waktu proses elektroplating 10, 15, 20 menit setiap spesimen uji. Setelah selesai maka dilanjutkan tahap pencucian akhir speseimen uji. Setelah dilakukan proses Elektroplating dengan variasi parameter kuat arus dan waktu pencelupan spesimen maka selanjutnya akan dilakukan pengujian kekereasan, pengujian foto makro dan pengujian laju korosi dengan tujuan untuk menganalisis hasil penelitian yang telah dilakukan.

\section{Hasil dan pembahasan}

\subsection{Foto Makro Hasil Pelapisan Nikel}

Foto makro hasil coating nikel merupakan foto perbandingan antara spesimen yang belum coating dan spesimen yang sudah di coating nikel menggunakan arus 3 ampere, seperti terlihat pada Gambar 2 Foto makro hasil coating.

Gambar 2 (a) menunjukan hasil pelapisan nikel dengan waktu 10 menit, dari hasil foto makro terlihat nikel yang menempel masih kurang rata dan terlihat masih belum sempurna serta sedikit kasar. Gambar 5 (b,c) pelapisan nikel dengan waktu pencelupan 20 dan 25 menit, dari hasil foto makro terlihat mirip, namun pada spesimen (b) 20 menit pencelupan, terlihat nikel yang menempel masih kurang halus rata dibandingkan dengan spesimen (c), terlihat nikel yang menempel sudah merata dan permukaannya lebih halus. Disebabkan karena semakin lama waktu pencelupan serta 
Kardiman dkk /Jurnal Rekayasa Mesin

p-ISSN: 1411-6863, e-ISSN: 2540-7678

Vol.16, No.2, Agustus 2021, hal. 172-180

semakin tinggi kuat arus yang diberikan berpengaruh pada proses perpindahan ion positif ke negatif, sehingga menjadikan hasil elektroplating menjadi lebih halus dan merata. Selain itu lama pencelupankan juga meningkatkan ketebalan lapisan pada permukaan katoda sehingga katoda akan semakin berat dikarenakan pada arus yang konstan, waktu yang semakin meningkat mengakibatkan dampak terhadap pengendapan ion yang meningkat pada permukaan katoda dan akan berdampak terhadap ketebalan permukaan logam induk sebagai katoda. Mengalirnya arus listrik searah melalui suatu larutan berkaitan dengan gerak partikel bermuatan [8].

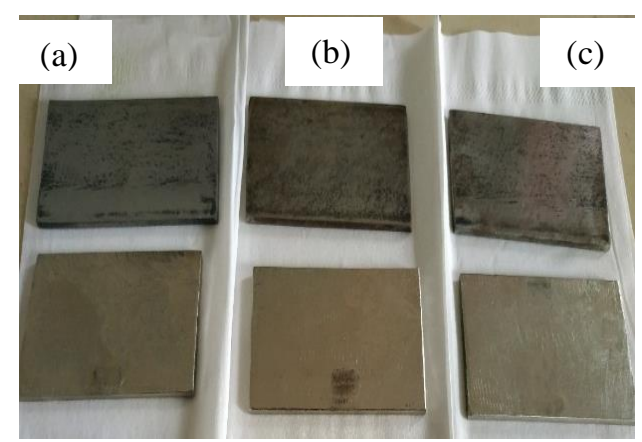

Gambar 2. Foto makro hasil pelapisan (a) dengan waktu 10 menit, (b) dengan waktu 20 menit, dan (c) dengan waktu 25 menit

Hal ini dibutikan oleh penelitian Ahmad (2011) menggunakan metode elektroplating dengan variasi waktu pelapisan 4, 8, dan 12 menit. Hasil penelitian menunjukan bahwa semakin lama proses pencelupan maka akan semakin tebal nikel yang menempel pada spesimen uji. Waktu pencelupan yang lama akan menyebabkan waktu perpindahan ion positif ke negatif lebih lama [9]. Selain meningkatkan ketebalan logam induk lama waktu pelapisan juga sangat berpengaruh terhadap kekerasan spesimen seperti penelitian yang dilakukan oleh Najamudin (2019) mengatakan bahwa waktu pelapisan sangat mempengaruhi terhadap harga kekerasan brinell, karena semakin lama waktu pelapisan akan membuat harga kekerasan material menurun dikarenakan dalam keadaan murni, nikel bersifat lembek tetapi jika dipadukan dengan chrome akan menjadi lebih keras [10].

\subsection{Hasil Uji Kekerasan}

Pengujian kekerasan pada penelitian ini dilakukan di Laboratorium Akademi Teknik Mesin Industri Cikarang. Data kekerasan benda uji diperoleh melalui pengujian kekerasan dengan menggunakan alat uji Rockwell, Indentor yang digunakan adalah kerucut intan dengan sudut puncak $120^{\circ}$ yang ditekan pada permukaan benda uji selama 45 detik dengan beban $150 \mathrm{kgf}$. Pengujian kekerasan dilakukan pada permukaan spesimen sebanyak 3 kali. Dari hasil pengujian tersebut didapatkan data pengujian seperti ditunjukan pada Tabel 1.

Tabel 1. Data Hasil Uji Kekerasan

\begin{tabular}{ccccccc}
\hline \multirow{2}{*}{ Spesimen } & \multirow{2}{*}{ Amper } & Menit & Data & Dekerasan (HRc) & Rata-rata (HRc) \\
\cline { 4 - 6 } & & & 1 & 2 & Data \\
Raw material & 2 & 10 & 15 & 15 & 17 & 15.67 \\
A & 2 & 20 & 15 & 16 & 16 & 15.67 \\
B & 2 & 20 & 15 & 16 & 19 & 17.17 \\
C & 3 & 10 & 20 & 20.5 & 19 & 16.33 \\
D & 3 & 20 & 19.5 & 21 & 20 & 19.83 \\
E & 3 & 25 & 20.5 & 20 & 20 & 20.17 \\
F & 3 & & & & 20.17 \\
\hline
\end{tabular}


Kardiman dkk /Jurnal Rekayasa Mesin

p-ISSN: 1411-6863, e-ISSN: 2540-7678

Vol.16, No.2, Agustus 2021, hal. 172-180

Untuk membahas hasil pengujian maka dilakukan analisis menggunakan grafik hasil pengujian tiap spesimen dari beberapa variasi kuat arus dan lama pencelupan, seperti ditunjukan pada Gambar 3 Grafik hubungan antara nilai kekerasan terhadap waktu pencelupan.

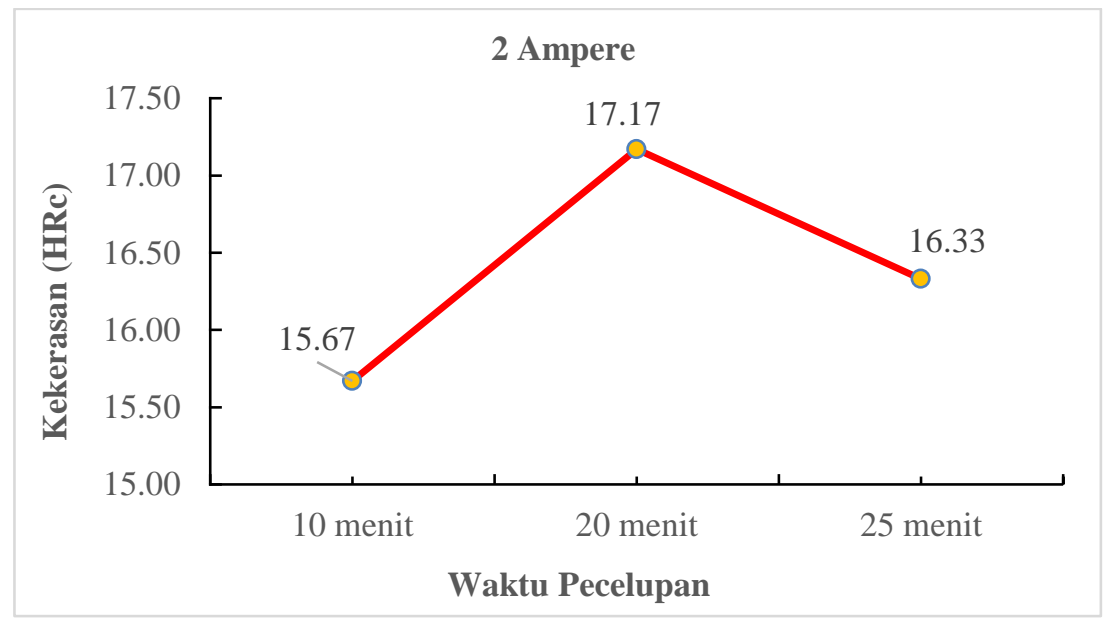

Gambar 3. Grafik hubungan antara kerkerasan terhadap waktu pencelupan kuat arus 2 ampere

Gambar 3 merupakan grafik hubungan antara kerkerasan terhadap waktu pencelupan 10, 20, 25 menit kuat arus yang digunakan adalah 2 ampere. Dari hasil pengujian terlihat bahwa pada waktu pencelupan 10 menit nilai kekerasan yang terjadi adalah $15.67 \mathrm{HRc}$ dan terjadi peningkatan nilai kekerasan, pada waktu pencelupan 20 menit sebesar 17.17 HRc selanjutnya mengalalami penurunan nilai kekerasan, pada waktu pencelupan 25 menit sebesar $16.33 \mathrm{HRc}$. Waktu pencelupan sangat berpengaruh terhadap nilai kekerasan yang menyebabkan semakin banyak ion nikel yang mengendap sehingga ketebalan semakin meningkat dan akan menyebabkan nikel akan semakin lunak dikarenakan tidak diikuti dengan peningkatan arus [10]. Hal tersebut membuktikan bahwa lama pencelupan tidak selalu meningkatkan nilai kekerasan tanpa diikuti dengan peningkatan arus eletroplating.

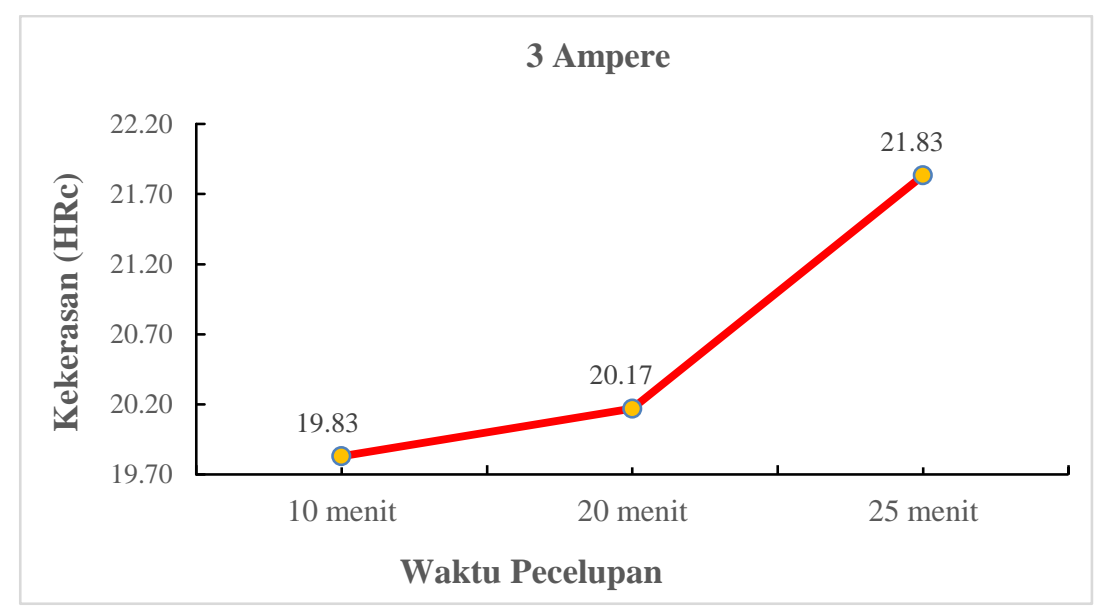

Gambar 4. Grafik hubungan antara kerkerasan terhadap waktu pencelupan kuat arus 3 ampere

Pengaruh kuat arus terhadap nilai kekerasan secara umum sangat berpengaruh terhadap peningkatan nilai kekerasan seperti yang ditunjukan pada Gambar 4. Grafik hubungan antara kerkerasan terhadap waktu pencelupan kuat arus 3 ampere. Telihat bahwa pada awal pencelupan 10 menit nilai kekerasan yang dihasilkan adalah 19.83 HRc dan pada 20 
Kardiman dkk /Jurnal Rekayasa Mesin

p-ISSN: 1411-6863, e-ISSN: 2540-7678

Vol.16, No.2, Agustus 2021, hal. 172-180

menit pencelupan terlihat nilai kekeresan sudah meningkat yakni 20.17 HRc selanjutnya diikuti dengan peningkatan signifikan pada waktu 25 menit pencelupan sebesar 21.83 HRc.

Berdasarkan Gambar 3 dan Gambar 4 menujukan bahwa penignkatan nilai kekerasan menigkat sering dengan meningkatnya arus elektrolapalting, selain itu lama pencelupan juga sangat berpengaruh terhadap nilai kekerasan. Hal tersebut terjadi karena seiring dengan meningkatnya kuat arus proses reaksi pengendapan ion elektrolit nikel menjadi lebih cepat, sehingga akan lebih banyak atom hidrogen yang masuk secara interstisi kedalam struktur endapan nikel [11].

Penelitian yang dilakukan oleh Rasyad dan Budianto (2019) yang meneliti tentang pengaruh nilai kekerasan terhadap kuat arus, dari hasil penelitianya membuktikan bahwa terjadi peningkatan nilai kekerasan $100 \mathrm{VHN}$ kuat arus 6 A sedangakan pada kuat arus 4,5 amper nilai kekerasan yang dihasilkan yakni 96.33 dan 97.33 VHN [12]. Kenaikan nilai kekerasan (VHN) disebabkan oleh kenaikan kuat arus dan lama pencelupan, semakin tinggi kuat arus serta semakin lama pencelupan maka jumlah muatan yang mengalir dan menempel pada katoda akan semakin banyak dan menyebabkan lapisan yang dihasilkan semakin tebal dan akan mempengaruhi laju korosi spesimen tersebut [13].

Oleh karena itu lama pencelupan dan larutan elektrolit eletroplating sangat berpengaruh terhadap nilai kekerasan setiap lapisan, itu dikarenakan kandungan logam nikel dari setiap larutan elektrolit bermacam-macam yang dapat mempengaruhi kuat arus yang mengalir di dalam larutan. Dalam penelitian ini jenis larutan sulfat klorida merupakan larutan elektrolit dengan kandungan logam tertinggi, disusul oleh larutan klorida dan selanjutnya larutan sulfat.

\subsection{Hasil Uji Laju Korosi}

Korosi dapat dikatakan sebagai penurunan kualitas logam, korosi dapat terjadi akibat reaksi elektrokimia antara logam dengan lingkungan. Salah satu kondisi lingkungan yang sering mengakibatkan korosi pada besi adalah air laut [14]. Pada Tabel 2 merupakan data hasil pengujian korosi yang telah dihitung berdasarkan persamaan yang digunakan.

Tabel 2. Data Hasil Uji Laju Korosi

\begin{tabular}{ccccccc}
\hline \multirow{2}{*}{ Spesimen } & Amper & Menit & $\begin{array}{c}\text { Massa spesimen } \\
\text { Sebelum }\end{array}$ & $\begin{array}{c}\text { Setelah } \\
\text { Direndam }(g r)\end{array}$ & $\begin{array}{c}\text { Massa yang } \\
\text { Direndam }(g r)\end{array}$ & $\begin{array}{c}\text { Nilai Laju Korosi } \\
\text { (mmpy) }\end{array}$ \\
\hline Raw & & & & & \\
Material & & & 46.72 & 46.65 & 0.07 & 2424.25 \\
1 & 2 & 10 & 44.12 & 44.07 & 0.05 & 1731.61 \\
2 & 2 & 20 & 46.22 & 46.18 & 0.04 & 1385.28 \\
3 & 2 & 25 & 45.3 & 45.26 & 0.04 & 1385.28 \\
4 & 3 & 10 & 46.1 & 46.07 & 0.03 & 1038.96 \\
5 & 3 & 20 & 49.01 & 49 & 0.01 & 346.32 \\
6 & 3 & 25 & 47.62 & 47.61 & 0.01 & 346.32 \\
\hline
\end{tabular}

Dilihat dari Tabel 2. bahwa besarnya kuat arus dan lamanya waktu proses pencelupan berpengaruh pada nilai laju korosi. Semakin lama waktu proses elektroplating semakin baik juga laju korosi, begitu pula dengan arus yang digunakan, semakin besar kuat arus maka akan berpengaruh pada semakin baik laju korosi yang didaptakan [7]. Seperti ditunjukan pada Gambar 5 Grafik Nilai laju korosi terhadap waktu pencelupan. 
Kardiman dkk /Jurnal Rekayasa Mesin

p-ISSN: 1411-6863, e-ISSN: 2540-7678

Vol.16, No.2, Agustus 2021, hal. 172-180

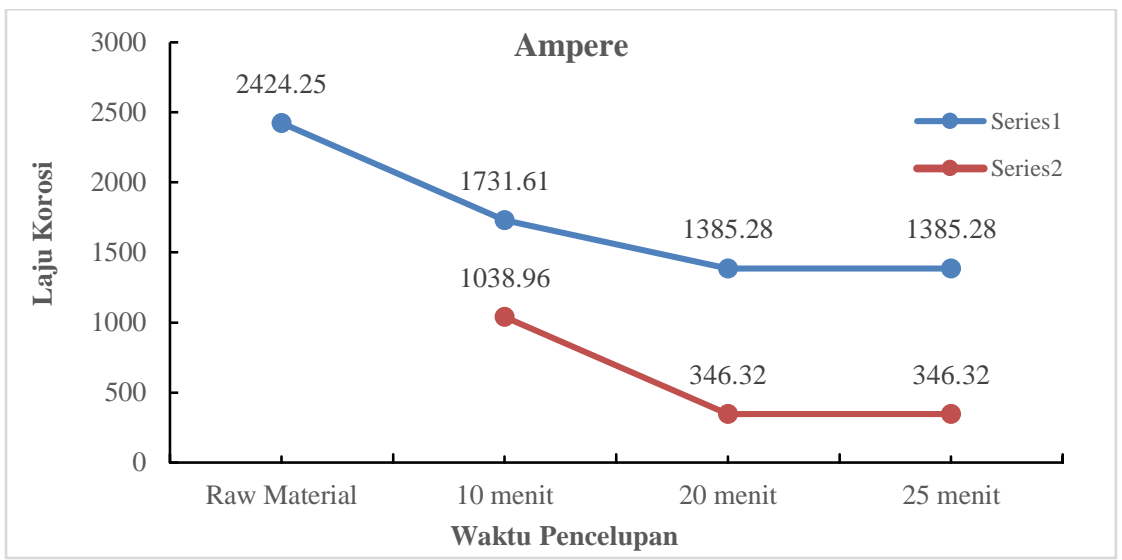

Gambar 5. Grafik hubungan antara laju korosi terhadap waktu pencelupan.

Pada Gambar 5. merupakan hubungan antara laju korosi terhadap waktu pencelupan dengan 2 variasi arus series1 2 ampere dan series1 3 ampere. Terlihat bahwa tanpa proses elektroplating atau raw material nilai laju korosi yang didapatkan adalah 2424.25 mmpy. Setelah dilakukan proses elektroplating 2 ampere dengan variasi lama pencelupan 10 nilai laju korosi yang didapat yakni 1038.96 mmpy dan pecelupan 20, 25 menit nilai laju korosi yang dihasilkan adalah 346.32 mmpy. Sedangkan pada arus 3 ampere terlihat mirip dengan hasil 2 ampere dimana nilai yang didapatkan semakin menurunun, pada waktu pencelupan 10 menit nilai yang didapatkan 1731.61 mmpy dan 20 , 25 menit pencelupan nilai yg dihasilkan $1385.28 \mathrm{mmpy}$. Variasi kuat arus dan waktu pencelupan pada proses eletroplating nikel sangat berpengaruh terhadap laju korosi, kehadiran nikel akan menunda pembentukan fasa intermetalik yang merusak fasa austenit sehingga membuat Sruktur FCC memiliki ketahanan korosi yang baik. Elemen nikel akan bereaksi dengan oksigen yang ada didalam air dan udara sehingga membentuk lapisan tipis yang stabil sehingga membentuk oksida dan hidroksida pada spesimen baja $[8,15]$.

Penelitian yang dilakukan Pratiwi dkk (2019) juga mebukitkan bahwa peningkatan kuar arus dan lama waktu pencelupan pada proses elektroplating maka nilai laju korosi yang dihasilkan semakin menurun [16]. Selanjutnya Viktor Malau (2011) juga telah melakukan penelitian menggunakan jenis larutan elektrolit all sulfat dan diuji laju korosinya menggunakan larutan Nacl 1\%, hasilnya nilai laju korosi baja sebelum dilapisi nikel yaitu 0.09076 mmpy sedangkan nilai laju korosi dari baja yang telah dilapisi oleh nikel menurun dengan nilai sekitar 0.03900 mmpy [17]. Pada pengujian ini media yang digunakan adalah larutan garam $\mathrm{NaCl}$ yang disemprotkan pada permukaan spesimen, karena semakin tebal dan rapatnya suatu lapisan nikel mengakibatkan semakin sulitnya larutan $\mathrm{NaCl}$ untuk bisa mengoksidasi spesimen tersebut dan ditambah lagi dengan sifat nikel yang tahan karat, sehingga permukaan baja karbon sulit untuk teroksidasi. Semakin besarnya logam yang terkandung dalam suatu larutan elektrolit berbanding lurus dengan semakin kecilnya laju korosi material tersebut [12].

\section{Kesimpulan}

Berdasarkan hasil pengujian serta menganalisa data yang telah dilakukan, maka dapat diambil kesimpulan sebagai berikut:

1. Dari hasil foto makro menunjukan bahwa pada pelapisan nikel dengan waktu 10 menit, terlihat nikel yang menempel masih kurang rata dan terlihat masih belum sempurna serta sedikit kasar dan pada waktu pencelupan 
Kardiman dkk /Jurnal Rekayasa Mesin p-ISSN: 1411-6863, e-ISSN: 2540-7678

Vol.16, No.2, Agustus 2021, hal. 172-180

20 menit nikel yang menempel sudah mulai halus namun belum sempurna sedangkan pada waktu peceleupan 25 menit terlihat bahwa nikel yang menempel sudah merata dan permukaan spesimen lebih halus.

2. Dari hasil pengujian kekerasan menujukan bahwa penigkatan nilai kekerasan menigkat sering dengan meningkatnya arus elektrolapalting.namun pada kuat arus proses elektroplating 2 ampere dengan lama pencelupan 25 menit hasil kekerasan menurun yakni 16.33 HRc dan nilai kekerasan tertinggi dihasilkan pada kuat arus 3 ampere dengan pada pencelupan 25 menit.

3. Dari hasil pengujian laju kororsi terlahat bahwa semakin tinggi kuat arus dan semakin lama proses pencelupan maka akan menurunkan nilai laju korosi, nilai laju korosi yang paling tinggi terjadi pada raw material yaitu 2424.25 mmpy sedangakan nilai laju korosi terendah adalah 1385.28 mmpy dengan lama pencelupan 25 menit dan kuar arus 3 ampere.

\section{Ucapan terima kasih}

Penulis berterimakasih kepada Risetdikti yang telah memberikan dana penelitian dosen pemula. Penulis juga mengucapkan terimakasih kepada dosen-dosen Prodi Teknik Mesin Fakultas Teknik Universitas Singaperbangsa Karawang yang telah banyak membantu serta telah memberikan tempat selama meyelesaikan penelitian ini.

\section{Daftar Pustaka}

[1] I Made Sudana, Ida Ayu Anom Arsani dan I.G.N Suta Waisnawa, "Alat Simulasi Pelapisan Logam dengan Metode Elektroplating," Jurnal Logic, vol. 14, no. 3, pp. 190-196, 2014.

[2] Paridawati, "Analisa Besar Pengaruh Tegangan Listrik Terhadap Ketebalan Pelapisan Chrome Pada Pelat Baja Dengan Proses Elektroplating," Jurnal Ilmiah Teknik Mesin, vol. 1, no. 1, pp. 35-44, 2013.

[3] A. Noor Setyo HD, Sri Widodo, "Pengaruh Energi Aktivitas Logam Pelapis Terhadap Ketebalan dan Laju Korosi Plating," Journal of Mechanical Engineering, vol. 3, no. 1, pp. 8-14, 2019.

[4] Eddy Triyono, Suparni Setyowati Rahayu,Vonny Siti Anggraini Budiarti, "Penerapan Teknologi Elektroplating pada Industri Kecil Knalpot di Purbalingga," Jurnal Dinamis, vol. Volume 8, no. Nomor 2, pp. 101-109, 2019.

[5] Basmal,Bayuseno, Sri Nugroho, "Pengaruh Suhu Dan Waktu Pelapisan Tembaga-Nikel Pada Baja Karbon Rendah Secara Elektroplating Terhadap Nilai Ketebalan dan Kekasaran," Rotasi, vol. 14, no. 2, pp. 23-28, 2012.

[6] Arif Surya Darmawan D.P, I Dewa Ketut Okariawan, Nasmi Herlina Sari, "Pengaruh Variasi Kuat Arus Listrik Dan Waktu Proses Electroplating Terhadap Kekuatan Tarik, Kekerasan dan Ketebalan Lapisan Pada Baja Karbon Rendah dengan Krom," Dinamika Teknik Mesin, vol. 5, no. 2, pp. 66-71, 2015.

[7] Drs. Syafrul Hadi, M.Eng, "Pengaruh Pelapisan NIKEL (Ni) terhadap Laju Korosi pada Pompa Impeler Pompa," Jurnal Momentum, vol. 17, no. 1, pp. 73-77, 2015.

[8] Muhammad Syaiful Fadly, Muhammad Iqbal, Ramang Magga., "Efek Variasi Arus Dan Waktu Pencelupan Pada Proses Electroplating Plat Baja Komersil Terhadap Ketebalan Lapisan Dan Laju Korosi," Jurnal Mekanikal, vol. 10, no. 1, pp. 906-917, 2019.

[9] M. A. Ahmad, Analisa Pengaruh Besar Tegangan Listrik Terhadap Ketebalan Pelapisan Chrom Pada Pelat Baja Dengan Proses Elektroplating, Makassar: Universitas Hasannudin Makassar, 2011. 
Kardiman dkk /Jurnal Rekayasa Mesin

p-ISSN: 1411-6863, e-ISSN: 2540-7678

Vol.16, No.2, Agustus 2021, hal. 172-180

[10] Najamudin, Zein Muhamad, Kunarto, "Analisis Sifat Mekanis Pada Logam Dengan Metode Pelapisan VernikelChrome Yang Dipengaruhi Waktu Pelapisan," Jurnal Teknik Mesin Universitas Bandar Lampung, vol. 7, no. 1, pp. 19-27, 2019.

[11] Kevin Bimariga, Lukman Noerochiem, dan Haniffudin Nurdiansah, "Pengaruh Variasi Kuat Arus Terhadap Ketebalan, Kekerasan dan Ketahanan Korosi Hasil Elektroplating Nikel-Hard Chromium pada Baja AISI 4340," Jurnal Teknik Its, vol. 8, no. 1, pp. 12-16, 2019.

[12] Abdul Rasyad, Budi Arto, "Analisis Pengaruh Temperatur, Waktu, dan Kuat Arus Proses Elektroplating terhadap Kekuatan Tarik, Kekuatan Tekuk dan Kekerasan pada Baja Karbon Rendah," Jurnal Rekayasa Mesin, vol. 9, no. 3, pp. 173-182, 2019.

[13] Ananta, Riyan Hendra, "Pengaruh Variasi Waktu Celup Dan Kuat Arus Terhadap Ketebalan Permukaan dan Struktur Mikro Baja St41 Pada Proses Pelapisan Nikel," JTM, vol. 4, no. 3, pp. 479-488, 2016.

[14] Farida Ali, Desy Saputri, Raka Fajar Nugroho, "Pengaruh Waktu Perendaman dan Konsentrasi Ekstrak Daun Jambu Biji (Psidium Guajava, Linn) Sebagai Inhibitor Terhadap Laju Korosi Baja Ss 304 Dalam Larutan Garam Dan Asam," Teknik Kimia, vol. 1, no. 20, pp. 28-37, 2014.

[15] Andrisel Putri, Sri Handani, "Karakterisasi Sifat Mekanik Hasil Elektroplating Nikel Karbonat (Nico3) pada Tembaga (Cu)," Jurnal Fisika Unand, vol. 4, no. 1, pp. 83-90, 2015.

[16] Vania Mitha Pratiwi, Sulistijono, Mas Irfan P. Hidayat, Handis Zuniandra, "Pengaruh Variasi Waktu dan Temperatur Elektroplating Seng Terhadap Ketebalan, Kekuatan Lekat dan Ketahanan Korosi pada Baja," Jurnal Teknik Its, vol. 8, no. 2, pp. 218-223, 2019.

[17] Viktor Malau, Nelson Seleman Luppa, "Pengaruh Variasi Waktu dan Konsentrasi Larutan Nacl Terhadap Kekerasan dan Laju Korosi dari Lapisan Nikel Elektroplating Pada Permukaan Baja Karbon Sedang," in Fakultas Teknik Universitas Wahid Hasyim Semarang, Semarang, 2011. 